\title{
Efficiency Evaluation of Chinese Patent Medicine Listed Companies in China - A Stock Market Based on DEA Model
}

\author{
Kanlun Chen \\ School of Management, \\ CDUTCM \\ Chengdu, P. R. China \\ 540624432@qq.com
}

\author{
Wuyi Song \\ School of Management, \\ CDUTCM \\ Chengdu, P. R. China \\ $1124658201 @ q q . c o m$
}

\author{
Sheng Li \\ School of Management, \\ CDUTCM \\ Chengdu, P. R. China \\ soonl@sina.com
}

\begin{abstract}
In order to improve the level of business decision-making and promote the development of Chinese patent medicine companies, this paper selects 8 indicators in the financial statements of 23 related listed companies in China A stock market in 2016 as examples. By constructing the Chinese patent medicine performance efficiency index system, our research chooses to use DEA model to estimate the comprehensive technical efficiency, pure technical efficiency, scale efficiency and scale efficiency characteristics. The results show that the overall efficiency of Chinese patent medicine listed companies is at a medium high level and the input-output ratio is generally higher. However, most companies have different degrees of DEA ineffective which have relatively stable scale efficiency and poor pure technical efficiency. We report here that the corporate managers should optimize the allocation of enterprise resources and increase investment in $R \& D$ and innovation to promote the improvement of corporate economies of scale and profit growth on the basis of maintaining the current level of fiscal management.
\end{abstract}

Keywords-Operating efficiency; Chinese patent medicine listed companies; DEA model; Suggestion

\section{INTRODUCTION}

With the development of Chinese patent medicine in recent years, the country attaches significant importance to formulate Chinese medicine industrial development plan which makes an unprecedented opportunity for Chinese patent medicine companies. Chinese patent medicine listed companies represent the essential components of Chinese patent medicine industry which have already made a great achievement in capital market. With the implementation of the "13th Five-year plan" for the development of Chinese medicine and the "Chinese Medicine Law of the People's Republic of China", higher development requirements are raised to promote the transformation and upgrading of the Chinese medicine industry [1]. For the related companies, especially Chinese patent medicine listed companies, will face new development opportunities and market challenges [2].

Under this background, through performance analysis, with the study of the basic business capabilities and operating efficiency of Chinese patent medicine listed companies, it is necessary to analyze their potential problems in management and operations, which will help them to optimize the allocation of their own resources and promote business quality and efficiency.

Selecting 8 indicators in the financial statements of 23 Chinese patent medicine listed companies in China A stock market in 2016 as example, this paper constructs a Chinese medicine performance efficiency index system and choose BCC (R. D. Banker \&A. Charnes \& W. W. Cooper) model based on DEA method to study the efficiency of Chinese medicine listed companies. To ensure the rationality and comprehensiveness of the indicators selection, it is essential to make it double for the quantity of DMUs from the number of input-output indicators. So, there are 4 input and output indicators have been chosen for the number of DMUs in this study is 23 .

According to the relative efficiency study about selecting input and output indicators from DMU (Decision Making Unit) in DEA model, the comprehensive technical efficiency, pure technical efficiency, scale efficiency and scale efficiency characteristics of 23 Chinese patent medicine companies are calculated. And the operating efficiency of each Chinese patent medicine listed company can be evaluated with the relaxation 
variables which are calculated from input and output indicators in BBC model.

\section{MODEL SETTING}

Data Envelopment Analysis (DEA) is a non-parametric system analysis method that uses a mathematical programming model to evaluate the relative efficiency of DMUs of the same type with multiple inputs and outputs indicators at the same time. It is mainly used to measure the output-to-input ratio of a business or industry at present. With the development of DEA model, there are more and more analysis models put forward by scholars, such as CCR (A. Charnes \& W. W. Cooper \& E. Rhodes) model and BCC model [3]. Considering that CCR model can't respond to the scale validity, this paper intends to use CCR model and BCC model in the DEA method to evaluate the performance of the Chinese patent medicine listed companies, and the model is defined as follows:

If there are $\mathrm{m}$ Chinese patent medicine listed companies (DMUs) to be analyzed, denoted byDMU $U_{k}, 1 \leq k \leq m$. Each DMUs has x inputs, then inputs are $R_{k}$

$$
R_{k}=\left(r_{1 k}, r_{2 k}, \ldots, r_{x k}\right)^{T}, k=1,2, \cdots, m
$$

According to the $\mathrm{m}$ inputs, each input indicator corresponds to the y output indicator, and the output y is:

$$
Y_{k}=\left(Y_{1 k}, Y_{2 k}, \ldots, Y_{y k}\right)^{T}, k=1,2, \cdots, m
$$

In order to avoid cone conditions in the setting process, the scale of income doesn't change, we need to add a convex assumption:

$$
\sum_{k=1}^{m} \lambda_{k}=1
$$

Considering the operating performance of 23 DMUs as a constraint, this paper takes the operating performance of $k_{0}$ as an analysis target. By introducing the dual programming model corresponding to the evaluation object, the values of the relaxation variables $S^{+}$and remaining variables $S^{-}$are obtained to judge its room for improvement. Here come the following equality constraints:

CCR model:

$$
\begin{aligned}
& \alpha^{*}=\min \left[\alpha-\varepsilon\left(\sum_{i=1}^{x} s_{i}^{-}+\sum_{r=1}^{x} s_{r}^{+}\right)\right] \\
& \text {s.t. }=\left\{\begin{array}{c}
\sum_{k=1}^{m} \lambda_{k}+s^{-}=\alpha R_{k 0} \\
\sum_{k=1}^{m} Y_{k} \lambda_{k}-s^{+}=Y_{k 0} \\
0 \leq \lambda_{k} ; k=1,2, \cdots, m \\
0 \leq s^{+} ; 0 \leq s^{-}
\end{array}\right.
\end{aligned}
$$

In this formula, min represents the minimum value, s.t. represents the constraint condition, $\alpha^{*}$ represents the overall efficiency evaluation result, $\varepsilon$ represents the non Archimedean infinitesimal, $R_{k}$ and $Y_{k}$ represent the input and output vectors, $s^{+}$and $s^{-}$represent the introduced slack variable and residual variable, $\lambda_{k}$ represents the combination coefficient of each evaluation unit.

In the CCR model, there are three kinds of decision theorem for the DMUs:

If $\alpha^{*}=1, s_{i} 0^{-}=0, s_{r} 0^{+}=0$, it can be determined that the comprehensive technical efficiency of the Chinese patent medicine listed companies is valid not only in technical efficiency but also in scale efficiency.

If $\alpha^{*}=1$, there comes at least one of the $s_{i} 0^{-}$and $s_{r} 0^{+}$is not 0 , it can be determined that the comprehensive technical efficiency of this Chinese patent medicine company is weak, but this DMU has invalid in technique or scale.

If $\alpha^{*}<1$, it can be determined that this DMU is completely invalid in comprehensive technical efficiency.

BCC model:

$$
\begin{aligned}
\beta^{*} & =\min \left[\alpha-\varepsilon\left(f_{e}^{T} s^{-}+f_{j}^{T} s^{+}\right)\right] \\
\text {s.t. }= & \left\{\begin{array}{l}
\sum_{k=1}^{m} \lambda_{k} R_{k}+s^{-}=\alpha R_{k 0} \\
\sum_{k=1}^{m} \lambda_{k} Y_{k}-s^{+}=Y_{k 0} \\
\sum_{k=1}^{m} \lambda_{k}=1 \\
0 \leq \lambda_{k} ; k=1,2, \ldots, m \\
0 \leq s^{+} ; 0 \leq s^{-}
\end{array}\right.
\end{aligned}
$$

In this formula, $\beta^{*}$ represents pure technical efficiency evaluation results and others such as min, s.t, $\varepsilon, R_{k}, Y_{k}$ $, s^{+}, s^{-}, \lambda_{k}$ represent the same contents in CCR model.

\section{DEA COMPREHENSIVE TECHNICAL EFFICIENCY CAlCulation}

This paper mainly uses data from the 2016 publicly reported performance reports of the 23 Chinese patent medicine listed companies, which is collected from the website of the Cninf, a website designated by China Securities Regulatory Commission. The calculation of input and output efficiency by using CCR and BCC model in DEA method, we need to firstly determine the input variables and output variables. The input variables are the fixed asset rate, the total asset rate, the current asset turnover rate and the inventory turnover rate. And the output variables are the net assets per share, the operating profit margin, the operating net profit and the asset profit rate, which are represent the profitability and the market influence in the business process of the DMUs. Other variables such as the fixed asset rate and the total asset rate represent the overall strength and development ability of the DMUs and the current asset turnover rate and the inventory 
turnover rate represent the continuous turnover input capacity of the DMUs. Input and output variables and factors are shown

TABLE I

DATE VARIABLES

\begin{tabular}{|c|c|}
\hline Input variables & Output variables \\
\hline the fixed asset rate & the net assets per share \\
\hline the total asset rate & the operating profit margin \\
\hline the current asset turnover rate & the operating net profit \\
\hline the inventory turnover rate & the asset profit rate \\
\hline
\end{tabular}

Using the software Deap 2.1 to calculate the comprehensive technical efficiency, pure technical efficiency, scale efficiency and scale efficiency characteristics of the 23

TABLE II 4 KINDS OF THE EFFICIENCY OF THE DMUS

\begin{tabular}{|c|c|c|c|c|}
\hline Name of the company & $\begin{array}{l}\text { Comprehensive } \\
\text { technical efficiency }\end{array}$ & $\begin{array}{l}\text { Pure technical } \\
\text { efficiency }\end{array}$ & Scale efficiency & $\begin{array}{l}\text { Scale efficiency } \\
\text { characteristics }\end{array}$ \\
\hline $\begin{array}{l}\text { BUCHANG } \\
\text { PHARMACEUTICAL }\end{array}$ & 1.000 & 1.000 & 1.000 & 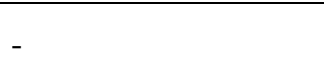 \\
\hline PIEN TZE HUANG & 1.000 & 1.000 & 1.000 & - \\
\hline $\begin{array}{ll}\text { ZHONGHENG } & \text { GROUP } \\
\text { PHARMACEUTICAL }\end{array}$ & 1.000 & 1.000 & 1.000 & - \\
\hline $\begin{array}{l}\text { XINGUANG } \\
\text { PHARMACEUTICAL }\end{array}$ & 1.000 & 1.000 & 1.000 & - \\
\hline ZIXIN PHARMACEUTICAL & 1.000 & 1.000 & 1.000 & - \\
\hline YUNNAN PAIYAO & 1.000 & 1.000 & 1.000 & - \\
\hline $\begin{array}{l}\text { BAILING } \\
\text { PHARMACEUTICAL }\end{array}$ & 0.993 & 1.000 & 0.993 & DECREASE \\
\hline $\begin{array}{l}\text { JUMPCAN } \\
\text { PHARMACEUTICAL }\end{array}$ & 0.621 & 1.000 & 0.621 & DECREASE \\
\hline $\begin{array}{l}\text { LINGRUI } \\
\text { PHARMACEUTICAL }\end{array}$ & 0.847 & 1.000 & 0.847 & DECREASE \\
\hline $\begin{array}{ll}\text { TIBET } & \text { RHODIOLA } \\
\text { PHARMACEUTICAL }\end{array}$ & 0.903 & 1.000 & 0.903 & INCREASE \\
\hline TONGRENTANG & 0.829 & 0.852 & 0.973 & INCREASE \\
\hline $\begin{array}{l}\text { KANGMEI } \\
\text { PHARMACEUTICAL }\end{array}$ & 0.806 & 0.885 & 0.911 & INCREASE \\
\hline $\begin{array}{l}\text { SHANGHAIKAIBAO } \\
\text { PHARMACEUTICAL }\end{array}$ & 0.803 & 0.806 & 0.997 & DECREASE \\
\hline $\begin{array}{l}\text { XIANGXUE } \\
\text { PHARMACEUTICAL }\end{array}$ & 0.785 & 0.856 & 0.917 & INCREASE \\
\hline $\begin{array}{l}\text { ZHENDONG } \\
\text { PHARMACEUTICAL }\end{array}$ & 0.754 & 0.776 & 0.972 & INCREASE \\
\hline $\begin{array}{l}\text { KANGHUI } \\
\text { PHARMACEUTICAL }\end{array}$ & 0.655 & 0.763 & 0.858 & INCREASE \\
\hline YIBAI PHARMACEUTICAL & 0.404 & 0.537 & 0.752 & INCREASE \\
\hline KPC PHARMACEUTICAL & 0.289 & 0.473 & 0.612 & INCREASE \\
\hline $\begin{array}{l}\text { TALOPH } \\
\text { PHARMACEUTICAL }\end{array}$ & 0.269 & 0.457 & 0.590 & INCREASE \\
\hline $\begin{array}{l}\text { JIANMIN } \\
\text { PHARMACEUTICAL }\end{array}$ & 0.266 & 0.400 & 0.667 & INCREASE \\
\hline $\begin{array}{l}\text { QIANJIN } \\
\text { PHARMACEUTICAL }\end{array}$ & 0.263 & 0.391 & 0.674 & INCREASE \\
\hline $\begin{array}{l}\text { ZHONGXIN } \\
\text { PHARMACEUTICAL }\end{array}$ & 0.257 & 0.437 & 0.588 & INCREASE \\
\hline FUREN MEDICINES GROUP & 0.220 & 0.317 & 0.695 & INCREASE \\
\hline
\end{tabular}


As can be seen from table 2, we can calculate the average value from these three kinds of DMUs efficiency are $0.694,0.780,0.851$, which means the overall efficiency of this study is at the upper level. Here come 6 companies achieve DEA valid, which are BUCHANG PHARMACEUTICAL, PIEN TZE HUANG, ZHONGHENG GROUP PHARMACEUTICAL, XINGUANG PHARMACEUTICAL, ZIXIN PHARMACEUTICAL and YUNNAN PAIYAO. Moreover, there are 4 companies in other 17 DMUs are invalid in comprehensive technical efficiency due to their invalid scale efficiency, which are BAILING GROUP PHARMACEUTICAL, JUMPCAN PHARMACEUTICAL, LINGRUI PHARMACEUTICAL, TIBET RHODIOLA PHARMACEUTICAL. Otherwise, the last 13 companies both invalid in pure technical efficiency and scale efficiency.

With the further study from table 2, we can divide the comprehensive technical efficiency into four stages, namely, effective in DEA (EID), slightly ineffective in DEA (SID), moderately ineffective in DEA (MIID) and severely ineffective in DEA (SIID). According to this method, it is obviously that there are 6 companies belong to the SID (value of comprehensive technical efficiency between 0.8 and 1), 4 companies belong to the MIID (value of comprehensive technical efficiency between 0.6 and 0.8 ) and 7 companies belong to the SIID.

According to the value of pure technical efficiency in table 2, there are four companies which have got the pure technical efficiency is effective and the value is 1 except the other 6 comprehensive technical efficiency effectively companies. It shows that these companies have already got the technological capabilities to adapt to their own development in terms of drug R\&D, management innovation and resource allocation. So, it's time to maintain this advantage in their future development and gradually increase their scale efficiency. In other 13 companies, there are 4 DMUs in SID level, 2 DMUs in MIID level and 7 DMUs in SIID level. From the overall situation about the pure technical efficiency of 13 DMUs, pure technical efficiency is the key factor affecting the competitiveness of Chinese patent medicine listed companies [4]. At present, there are still much lack of an atmosphere of enterprise technology innovation and management innovation compatible with the development of Chinese medicine.

Consistent with the type classification of scale efficiency in DEA model, the stage of constant efficiency in scale is the stage when the input and output of the company reaches an optimal state. In the process of increasing scale efficiency, increasing input can significantly upsurge the efficiency of enterprises and raise the level of comprehensive technical efficiency [5]. But in enterprises with diminishing economies of scale, increasing input will not only increase the efficiency of the company, but also reduce the revenue of the company.

Through the analysis of the scale efficiency of 23 Chinese patent medicine listed companies, there are 6 companies have the same scale efficiency, accounting for $26.09 \%$ of the total. With the 12 companies in the stage of increasing scale efficiency, accounting for $52.14 \%$ of the total and the 5 companies in the stage of diminishing scale efficiency accounts for $21.71 \%$ of the total. We can find that firms with constant economies of scale should maintain their resource allocation status. Moreover, these companies should ensure their possibility of overcapacity is reduced and increase their input based on their pure technical efficiency or scale efficiency deficiencies to promote their output capacity. And the reasons for the decline in the scale efficiency of enterprises are complex, such as the inefficiency of the diversification of businesses and the waste of resources [6], the change of operating capacity caused by major asset acquisitions or transfers during the year and the changes in the management of the company.

Therefore, in the face of diminishing efficiency of scale, we can't only proceed from the perspective of reducing input. We must also optimize internal resource allocation, control cash flow stability in business operations and adapt management methods to the development of enterprises to advance operational efficiency at the same time [7].

\section{INEFFECTIVE TECHNICAL EFFICIENCY DMUS ANALYSIS}

With the BCC model used to calculate the slack variables $s^{+}$and $s^{-}$of 23 Chinese patent medicine listed companies, this paper make $s_{1}^{-} s_{2}^{-} s_{3}^{-}$and $s_{4}^{-}$respectively signify slack variable values of fixed asset rate, total asset turnover rate, inventory turnover rate and current asset turnover rate in the input indicator. And then, we make $s_{1}^{+} s_{2}^{+} s_{3}^{+}$and $s_{4}^{+}$ individually represent slack variable value of the operating net profit rate, asset profit rate, operating profit ratio and the net asset per share in the output indicator.

As can be seen from the Table 3, there are 13 DMUs plagued with redundant in-put and insufficient out need to make an adjustment. Among them, the inventory turnover of investment, the operating net margin of output and the operating margin of output have significant variations. It shows that 23 Chinese patent medicine listed companies generally have the ability to over-guarantee short-term solvency, resulting in excessive cash flow investment and a drop-in utilization rates. At the same time, the profitability of the finished pharmaceutical products is relatively small and the profit per unit product is lower. 
TABLE III RELAXATION VARIABLE VALUE OF INPUT-OUTPUT INDEX

\begin{tabular}{|c|c|c|c|c|c|c|c|c|}
\hline $\begin{array}{c}\text { NAME OF THE } \\
\text { COMPANY }\end{array}$ & $\boldsymbol{s}_{\mathbf{1}}^{-}$ & $\boldsymbol{s}_{\mathbf{2}}^{-}$ & $\boldsymbol{s}_{\mathbf{3}}^{-}$ & $\boldsymbol{s}_{\mathbf{4}}^{-}$ & $\boldsymbol{s}_{\mathbf{1}}^{+}$ & $\boldsymbol{s}_{\mathbf{2}}^{+}$ & $\boldsymbol{s}_{\mathbf{3}}^{+}$ & $\boldsymbol{s}_{\mathbf{4}}^{+}$ \\
\hline $\begin{array}{c}\text { KANGHUI } \\
\text { PHARMACEUTICAL }\end{array}$ & 0.000 & 0.014 & 0.000 & 0.000 & 0.128 & 0.036 & 0.135 & 0.000 \\
\hline $\begin{array}{c}\text { JIANMIN } \\
\text { PHARMACEUTICAL }\end{array}$ & 0.000 & 0.056 & 2.887 & 0.000 & 0.215 & 0.089 & 0.249 & 0.000 \\
\hline $\begin{array}{c}\text { FUREN MEDICINES } \\
\text { GROUP }\end{array}$ & 0.800 & 0.000 & 0.538 & 0.290 & 0.164 & 0.007 & 0.157 & 0.840 \\
\hline $\begin{array}{c}\text { YIBAI } \\
\text { PHARMACEUTICAL }\end{array}$ & 0.000 & 0.000 & 0.488 & 0.000 & 0.147 & 0.019 & 0.128 & 0.000 \\
\hline $\begin{array}{c}\text { KANGMEI } \\
\text { PHARMACEUTICAL }\end{array}$ & 0.000 & 0.013 & 0.000 & 0.000 & 0.082 & 0.021 & 0.067 & 0.000 \\
\hline $\begin{array}{c}\text { QIANJIN } \\
\text { PHARMACEUTICAL }\end{array}$ & 0.000 & 0.000 & 0.732 & 0.000 & 0.196 & 0.042 & 0.205 & 0.412 \\
\hline $\begin{array}{c}\text { KPC } \\
\text { PHARMACEUTICAL }\end{array}$ & 0.000 & 0.000 & 0.787 & 0.000 & 0.153 & 0.029 & 0.178 & 1.151 \\
\hline $\begin{array}{c}\text { ZHONGXIN } \\
\text { PHARMACEUTICAL }\end{array}$ & 0.000 & 0.000 & 0.788 & 0.000 & 0.163 & 0.039 & 0.188 & 0.092 \\
\hline $\begin{array}{c}\text { TALOPH } \\
\text { PHARMACEUTICAL }\end{array}$ & 0.000 & 0.000 & 0.994 & 0.000 & 0.202 & 0.038 & 0.196 & 0.642 \\
\hline TONGRENTANG & 0.003 & 0.183 & 0.000 & 0.063 & 0.164 & 0.000 & 0.128 & 0.000 \\
\hline $\begin{array}{c}\text { ZHENDONG } \\
\text { PHARMACEUTICAL }\end{array}$ & 0.019 & 0.000 & 2.524 & 0.156 & 0.112 & 0.031 & 0.116 & 0.000 \\
\hline $\begin{array}{c}\text { XIANGXUE } \\
\text { PHARMACEUTICAL }\end{array}$ & 0.044 & 0.000 & 2.238 & 0.174 & 0.156 & 0.027 & 0.159 & 0.000 \\
\hline $\begin{array}{c}\text { SHANGHAIKAIBAO } \\
\text { PHARMACEUTICAL }\end{array}$ & 0.000 & 0.044 & 0.000 & 0.000 & 0.073 & 0.000 & 0.094 & 0.562 \\
\hline
\end{tabular}

Consequently, Chinese patent medicine listed companies should increase the use of cash flow in their operations, increase the use of drug R\&D funds and ensure innovation ability. At the same time, Chinese patent medicine companies should make full use of the historical opportunity of the country to vigorously develop traditional Chinese medicine, promote its production transformation and upgrade [8]. They should actively expand sales channels and rationally allocate market competition input resources, which can improve their drug quality and social influence. To increase the demand and influence of the consumer market, these companies should increase their business profit with the increase in the demand for drugs from consumers [9]. With the problem of low operating efficiency caused by input redundancy alleviated, the companies should enhance input-output ratios and promote technological efficiency to reach scale efficiency and technical efficiency effective in DEA.

\section{CONCLUSION AND RECOMMENDATION}

In this paper, CCR model and BCC model of DEA method are used to study the efficiency of Chinese patent medicine listed companies by using panel date of 23 related listed companies whose core business is proprietary Chinese patent medicines related businesses in 2016. This paper selects the 8 indicators like the fixed asset rate, the total asset rate, the current asset turnover rate and the inventory turnover rate as input variables and the net assets per share, the operating profit margin, the operating net profit and the asset profit rate as output variables. This paper chooses CCR model and BCC model in DEA method to calculate the comprehensive efficiency, pure technical efficiency, scale efficiency and analysis the improvement of ineffective technical efficiency DMUs.

The calculation results show that, as the data from 23 Chinese patent listed companies in 2016, the comprehensive technical efficiency of most DMUs in this study have already reached a relatively high level of their own company during years of their operation. But they are still in a weak position in terms of drug research and development, technological innovation, etc., which let them can't have high technical efficiency. The results of the pure technical efficiency of this DMUs show that most of Chinese patent medicine listed companies have already made a good balance between input and output. But the level of management resource administration still become a potential problem in some companies, which will let the companies trapped in the passive position of market competition and decrease the average value of production efficiency in this industry. Seen from the scale efficiency of this DMUs, there are 6 companies have the same scale efficiency, accounting for $26.09 \%$ of the total. With the 12 companies in the stage of increasing scale efficiency, accounting for $52.14 \%$ of the total and the 5 companies in the stage of diminishing scale efficiency accounts for $21.71 \%$ of the total.

Based on the empirical results, we propose the following suggestion to increase the operation efficiency in Chinese patent medicine listed companies:

Firstly, company managers should maintain a flexible financial performance and rationally allocate firms resources. Chinese patent medicine listed companies should pay attention to their fiscal management. They should improve the economic management efficiency by optimizing financial structure and institution to reduce debt level to advance their monetary management personnel. At the same time, flexible and moderately fiscal management strategies should be adopted, and timely adjustments are made according to changes in external markets to allocate enterprise resources. With the financial control mechanism strengthened, these companies will advance their operating performance and strive to achieve 
an asset operating management level above the industry average.

Secondly, Chinese patent medicine listed companies should carry out cost forecasting and formulate scientific input and output indicators. They should establish their own input-output performance evaluation system with "cost reduction and efficiency increase" as the core, to reconstruct business and production processes. Moreover, these firms should strengthen price management and tenderly review in the procurement of raw materials to control procurement costs. Under the premise of enterprise layout, drug production and market demand, they should scientifically advance judgments and make reasonable choices to organize the procurement of raw materials and start the production. At the same time, in the evaluation of input and output indicators, not only must the implementation of financial indicators be detailed, but also the impact of nonfinancial indicators such as customer evaluation, quality control, and operations on corporate performance should be emphasized. Particularly, Chinese patent medicine listed companies should do a decent job of information disclosure so that the company's target management can truly serve its strategy.

Thirdly, enterprises should actively carry out corporate mergers and acquisitions, correct their merger motives and focus on improving scale efficiency. While focusing on the performance of the core business, company managers need to find new business growth engines to obtain continuous improvement in their market competitiveness and capital preservation capabilities. For example, through the platform of the capital market, such as mergers and acquisitions, these companies will absorb some resources like production ability, technology and knowledge in the industry to expand the scale of their companies. At the same time, these enterprises should actively explore the expansion of the major business to the upstream and downstream of the industrial chain, relying on the company's advantageous resources to drive peripheral businesses. These measures will benefit them to generate economies of scale and further improve the company's business concentration and operational efficiency.

Finally, these companies should improve the drug research and development personnel training system and enhance independent innovation. They should pay attention to the cultivation of drug R\&D personnel, take the road of independent research and development, and strive to cultivate high-performance drug R\&D teams with corporate characteristics and market sensitivity. On the one hand, companies should strengthen communication with scientific research institutions and institutions of higher learning to establish a personnel training and exchange mechanism. On the other hand, managers should make full use of policy resources to improve the scientific research environment, upgrade the level of hardware and software supporting facilities, support the construction of $R \& D$ protection platforms and promote the flow of drug $R \& D$ personnel within the industry. And they should improve the independent innovation level and sustainable development capability of the enterprise by clarifying the $R \& D$ route, enhance the team's R\&D effectiveness and establish their incentive mechanisms to ultimately promote the pure technical efficiency.

\section{REFERENCES}

[1] Notice of the State Administration of Traditional Chinese Medicine on Printing and Distributing the Thirteenth Five-Year Plan for the Development of Traditional Chinese Medicine [EB/OL], http://www.gov.cn/xinwen/2016-08/11/content_5098934.htm, 2016-08-11.

[2] The People's Republic of China Chinese Medicine Law [EB/OL], http://www.npc.gov.cn/npc/xinwen/2016-12/25/content_2004972.htm, 2016-12-25.

[3] BANKER R D, CHARNES A, COOPER W W Some models for estimating technical and scale inefficiencies in data envelopment analysis [J].Management science, 1984, 30(9):1078-92.

[4] Li Wei. Performance Evaluation of Financial Strategy of Listed Pharmaceutical Manufacturers[D]. Qiqihar University, 2013.(In Chinese)

[5] Chen Weizhong. Evaluation of Financial Performance of Listed Companies in Zhejiang Province Based on Factor Analysis [J/OL]. Modern Business Industry, 2015, (25): 1. (In Chinese)

[6] Shen Yuzhu. Research on the Performance of Chinese Time-honored Pharmaceutical Listed Companies[D]. Guangzhou University of Chinese Medicine, 2014. (In Chinese)

[7] $\mathrm{Hu}$ Yingying, $\mathrm{Xu}$ Wen, Wang Yuqiang. Empirical analysis of the operating performance of listed companies in traditional Chinese medicine [J/OL]. Chinese Pharmaceutical Affairs, 2015, 29(08): 788-792. (In Chinese)

[8] Qin Yu. Evaluation of financial performance of listed companies in Chinese medicine industry[D]. Anhui University of Finance and Economics, 2015. (In Chinese)

[9] Li Weilian. Empirical research on the relationship between business performance and valuation in pharmaceutical industry[D]. Shanxi University, 2014. (In Chinese) 